\title{
Two Layers of Repetition in Kate Morton's The House at Riverton
}

\begin{abstract}
The article discusses the two layers of repetition in Kate Morton's The House at Riverton (2006) and their mutual correlations. The first layer concerns the setting of some parts of the novel, namely the 1910s and 1920s. The past is relived in fiction, fuelled by the nostalgia for the pre-World War II days and the enduring interest in early $20^{\text {th }}$-century aristocrats, socialites, and war poets. The second layer involves the reconstruction of the past by means of a historical film and the reminiscences of Grace, the protagonist, who at the dusk of her life attempts to revive the tumultuous events she witnessed in her youth.
\end{abstract}

Keywords: repetition, nostalgia, biopic, reminiscences, reconstruction, Kate Morton.

\section{Introduction}

The present article sets out to examine the two layers of repetition in The House at Riverton by Kate Morton, first published in 2006. The first layer consists in the setting of some parts of the novel, namely the early $20^{\text {th }}$ century, which can be attributed to the nostalgia for the past. The second layer involves the modes of the reconstruction of the past and bringing it back to life, that is a historical film and the protagonist's voice recordings. Those two layers are at the core of the novel, contributing to its commercial success.

The House at Riverton is one of many contemporary novels, films, and TV series set in the first half of the $20^{\text {th }}$ century. This period enjoys renewed popularity among contemporary audiences, resulting in numerous stories with shared features. Those features include the setting in a British country house, upperclass characters who take their servants for granted, the focus on their glamorous lifestyle and their possessions, as well as the transition from an idyllic life into bleaker times, precipitated by a crisis (usually the outbreak of war). Those common themes can be traced back to the original fiction of the first half of the $20^{\text {th }}$ 
century, for example Evelyn Waugh's Brideshead Revisited (1945). In the $21^{\text {st }}$ century the past is repeated in literature and film but it is viewed from the modern perspective, which manifests itself for instance in giving a voice to servants, "an army of the unseen" (THR 35). Some examples of this trend include such novels as Ian McEwan's Atonement (published in 2001), Alan Hollinghurst's The Stranger's Child (published in 2011), and The House at Riverton, which is the subject of the present study. When it comes to film and television, Downton Abbey (2010-2015) is probably the most popular TV series about early $20^{\text {th }}$ century British aristocrats. It was awarded The Golden Globe Award in 2012, which attests to the appeal of its subject matter. What is also worth mentioning, there have been recent TV and film adaptations of classic $20^{\text {th }}$ century novels, which also fit the description: Bright Young Things (the adaptation of Evelyn Waugh's Vile Bodies, released in 2003), Brideshead Revisited (2008), ${ }^{1}$ Parade's End (2012), ${ }^{2}$ and The Go-Between (2015). ${ }^{3}$ Thus, common themes are frequently repeated with variations to satisfy the demand of the public fascinated with that era. The audience is drawn to the portrayals of the bygone splendour: aristocrats with their grand country houses, fancy clothes, and lavish parties; however, contemporary writers and filmmakers do not merely rely on the aesthetic aspect of that specific setting, venturing to explore such issues as class divisions and women's suffrage. The reconstruction of the past in The House at Riverton attempts to reconcile these two seemingly conflicting issues: the appeal of the past and the modern evaluation of its shortcomings.

\section{Nostalgia}

The popularity of the novels, films, and TV series set in the early $20^{\text {th }}$ century can be attributed to the nostalgia for the past. As John J. Su points out, nostalgia is a phenomenon prevalent in contemporary literature but it is commonly dismissed "as a form of amnesia". ${ }^{4}$ Nostalgia is often conflated with an idealisation of its subject but the repeated reoccurrence of the past may entail a fresh critical rendition of well-known themes. This is true for the modern representations of the early $20^{\text {th }}$ century, which refrain from glorifying the themes they portray, even though they rely on the interest in controversial issues, such as British aristocracy. Obviously, nostalgia is not exclusive to the $21^{\text {st }}$ century, as writers' interest in the past is as old as literature itself. While the first decades of the $20^{\text {th }}$ century have an appeal for $21^{\text {st }}$-century authors, writers of that era also set their books in earlier times. In his analysis of the early $20^{\text {th- }}$ century nostalgia, Stevenson claims that "[a]

\footnotetext{
1 Waugh's novel had been previously adapted in 1981 as a mini-series.

2 The adaptation of Ford Madox Ford's tetralogy.

3 The adaptation of L.P. Hartley's novel. The novel had been previously adapted in 1971 .

4 J.J. Su, Ethics and Nostalgia in the Contemporary Novel, Cambridge 2005, p. 2.
} 
uthors continue to look back, even over still-higher piles of debris, toward a sunny landscape $[\ldots]]^{\prime}{ }^{5}$

Although modern works set in the early $20^{\text {th }}$ century acknowledge the social inequalities and prejudices of the era, it can be assumed that their audience considers them escapist to an extent. Readers and viewers share Sebastian Flyte's famous wish: "If it could only be like this always - always summer, always alone, the fruit always ripe, and Aloysius in a good temper...", ${ }^{6}$ repeatedly turning to Arcadian themes in various incarnations. However, since our "days in Arcadia [are] numbered", ${ }^{7}$ the audience expects to be confronted with some conflict and underlying tensions, while simultaneously being drawn to the glamour of the ever-present country houses and the resplendent lives of their inhabitants.

The blurb of The House at Riverton draws on this fascination with the past:

Summer 1924: On the eve of a glittering Society party, by the lake of a grand English country house, a young poet takes his life. The only witnesses, sisters Hannah and Emmeline Hartford, will never speak to each other again (THR).

It is carefully phrased, aiming at attracting fans of historical novels, mysteries, and romances with a love triangle. Summer is a typical Arcadian setting and the word "glittering" is evocative, connoting sophistication and extravagance. Beauty, splendour, and wealth are contrasted with a tragedy, yet the wording of the blurb invites the reader to explore the mystery rather than mourn the victim of the alleged suicide.

Kate Morton, the author of The House at Riverton, who is a contemporary Australian writer, admits that she was influenced by her mother's Anglophilia when she was a child: "[...] I loved reading books about England - it sounded like a magic place where it snowed, with hedgerows and conkers", she remarks. ${ }^{8}$ Her sentimental attitude to Great Britain is common among non-British people and is tied with nostalgia. Tamarkin draws attention to the symbolic nature of Anglophilia and links it to nostalgia, also pointing out that it is fuelled by the mysteriousness of England. ${ }^{9}$ Great Britain is often romanticised by foreigners (but not exclusively) and the periods preceding both World Wars seem to be particularly alluring. The setting of contemporary renditions of those eras seems to be equally rooted in history and imagination, which results in numerous works repeating the same themes to satisfy the audience.

In The House at Riverton, the past is relived by Grace Bradley, the ninetynine-year-old protagonist. As a girl, Grace was a maid at Riverton. As a servant, she was always in the background of the important events unfolding at this stately

5 R. Stevenson, Remembering the Pleasant Bits: Nostalgia and the Legacies of Modernism, "NOVEL: A Forum on Fiction" 2010, vol. 43, no. 1, p. 134.

${ }^{6}$ E. Waugh, Brideshead Revisited, London 2011, p. 90.

7 Ibid., p. 149.

${ }^{8}$ Qtd. in L. Powell, The Lake House Author Kate Morton: I Wrote The House at Riverton During my Baby's Naptimes, “The Telegraph”, 14 May 2016.

9 E. Tamarkin, Anglophilia: Deference, Devotion, and Antebellum America, Chicago-London 2007, p. xii, xiv. 
home. She recalls the advice Mr Hamilton, the butler, gave her as she entered service:

Never forget $[\ldots]$ you are fortunate indeed to be invited to serve in a great house such as this. And with good fortune comes responsibility. [...] You know your job is done well when it goes unnoticed, that you have succeeded when you are unnoticed (THR 30).

This invisibility allowed her access to the lives of the Hartfords - Hannah, Emmeline, and David - as well as the poet Robert Hunter, which made her a witness of the events that would captivate the imagination of the subsequent generations. For Grace, the past is not something that is over; "[...] there was some part of me that never left that house. Rather, some part of that house that would never leave me", she admits, speaking of Riverton (THR 18). The past lives within Grace and she concludes that "[...] those who live in memories are never really dead" (THR 31).

Within the framework of the novel, the present exists to relive the past and uncover its mysteries but at the same time, the past can only be reconstructed through the present. The plot is constructed around several symbolic temporal landmarks. The first one is the year 1900, the beginning of a new era. Not long after midnight, Grace was born - a millennial child who would live for almost an entire century. In 1914 she became a maid at Riverton and soon "[ $\mathrm{t}$ ]he lamps [were] going out all over Europe [...]". ${ }^{10}$ Ten years later, the Bright Young People emerged - both in the novel and in real life. Taylor traces their "first colonizing army" (including Cecil Beaton and Evelyn Waugh) to $1924 .{ }^{11}$ The same year, the climax of the novel happens, when Robbie Hunter, a poet, war veteran, and socialite, allegedly kills himself. The contemporary part of the novel is set in 1999, when Grace is ninety-nine - the millennial craze that accompanied her birth is repeated as the new century approaches. Therefore, nostalgia relies on symbols and the illusion of time repeating itself on the eve of the new millennium.

\section{Reconstruction of the past}

The House at Riverton employs two modes of the reconstruction of the past: the production of a historical film and Grace's voice recordings. The former relies on the appeal that the story of the Hartfords and Hunter has for contemporary audiences:

[...] it's fascinating [...] A rising star of the English poetry scene kills himself by a dark lake on the eve of a huge society party. His only witnesses are two beautiful sisters who never speak to each other again. One his fiancée, the other rumoured to be his lover. It's terribly romantic (THR 17)

${ }^{10}$ Qtd. in B.W. Tuchman, The Guns of August, London 1962, p. 122. Sir Edward Grey's remark upon the outbreak of World War I.

11 D.J. Taylor, Bright Young People: The Rise and Fall of a Generation: 1918-1940, London 2007, p. 55. The Bright Young People (also known as the Bright Young Things) were young British socialites of the 1920s and 1930s, whose eccentric parties frequently made headlines. Their members include Beverley Nichols, Stephen Tennant, and Loelia Ponsonby (ibid., p. 19-20). 
This is the version of the story that has circulated for decades and Grace is the only surviving person who knows what really happened. Only she can revisit the past as it really was, not clouded by legends and lies.

Robbie Hunter is a Brookian figure - a poet, socialite, and soldier destined for a tragic death that would fascinate the posterity. Grace recollects how he seemed to make an instant impression on other people:

He was handsome. But who amongst the young is not? With him it was something more, the beauty of stillness. Alone in the room, his dark eyes grave beneath a line of dark brows, he gave the impression of sorrow past, deeply felt and poorly mended. He was tall and lean, though not so as to appear lanky, and his brown hair fell longer than was the fashion, some ends escaping others to brush against his collar, his cheekbone (THR 119).

Robbie's intriguing personality and his entanglement with the Hartford sisters, resulting in his alleged suicide, make him an ideal subject of a commercial biopic that is undertaken in the novel.

According to Welsh, the biopic as a film genre has steadily gained popularity from the 1980s onwards. ${ }^{12}$ He claims that biopics, concerned with such prominent figures as Malcolm X or Charlie Chaplin, in spite of their apparent biographical nature, employ some degree of artistic licence, concluding that "[o]n film, even more than on the printed page, history and biography are likely to become imaginative exercises, perhaps not intentionally designed to confuse the viewer, but resulting in confusion none the less". ${ }^{13}$ He calls this type of film "biofantasy" on account of its modifying the facts for dramatic purposes. ${ }^{14}$

The film about Hunter's alleged suicide is such a "biofantasy". Not only are the filmmakers not privy to the truth about his death and his relationship with the Hartford sisters, but they also elect to romanticise the story in order to make it more appealing to the audience:

"Near the lake?" I am confused. "But that's not where they met. It was the library, it was winter, they were"

"The library? [...] No wonder the scriptwriters changed it. There's nothing dynamic about a room full of old books. It works really well this way, the lake being where he killed himself and all. Kind of like the end of the story is the beginning. It's romantic" (THR 176-177).

The story is thus modified to render it more structured and impactful in spite of Grace's reservations. The past is now mouldable and at the mercy of the present.

"The historical film does not, any more than the written word, aim to deny or even alter a larger sense of history - its aim rather is to evoke and comment upon the past", remarks Rosenstone. ${ }^{15}$ The evocation of the past seems to be precisely what the film about Hunter and the Hartfords wants to achieve. The most tangible symbol of the reconstruction of the past is the film set established at Riverton.

12 J.M. Welsh, Hollywood "Faction" and the New Biofantasy, "Studies in Popular Culture" 1993, vol. 15 , no. 2 , p. $57-66$.

13 Ibid., p. 59.

14 Ibid., p. 57.

15 R.A. Rosenstone, The Reel Joan of Arc: Reflections on the Theory and Practice of the Historical Film, "The Public Historian”2003, vol. 25, no. 3, p. 76. 
When Grace sees it, she is impressed with the effort put into the recreation of the original drawing room. However, she cannot help noting that something is missing: "Someone had gone to a lot of trouble to get it right, but [the clock] announced itself an impostor with every tick" (THR 13). The film set, just like the film itself, is only an imitation, a replica of the past - created with dedication but not entirely managing to capture its spirit.

The film about Hunter and the Hartfords is an example of heritage cinema, which can be traced back to the $1930 \mathrm{~s} .{ }^{16}$ According to Claire Monk, heritage films are often criticised for their "preoccupation with bourgeois or upper-class subjects and their meticulous recreation and 'spectacular' display of period settings - particularly the iconography of a property-owning, highly class-specific pastoral 'Englishness"". ${ }^{17}$ Despite such criticisms, heritage films enjoy considerable popularity and the filmmakers in The House at Riverton seem to be aware that these features are what will attract the audience.

In the process of preparation for the film, Grace meets Keira, a young actress cast to play her role. "I am to be in the film", says Grace, "[w] ell, not me, but a young girl pretending to be me" (THR 171). Keira has to recreate a part of Grace's youth but Grace is equally reminded of her old age by Keira, who wants to take advantage of her being still alive to shine in her background role in order to be noticed by someone influential in the industry. She even suggests some alterations to what actually happened, baffled by the subservience that servants had to display. Therefore, Keira is another part of the replica that is meant to aesthetically captivate the audience but not necessarily stay true to the real story.

The other mode of the reconstruction of the past in The House at Riverton is Grace's own recollection. Burdened by her long-held secrets, she wants to finally share them with someone, so she records tapes for her grandson. Being ninetynine, her time is running out but she is resolved to fight her ageing body and mind to reveal her secret. In her tale, she goes back to her birth in 1900, when she made local headlines as the first child born that year. Now she is one of the remnants of that bygone era, so distant and yet so strangely fascinating for the younger generations. She focuses on the decade between her first day at Riverton in 1914 and the tragedy of 1924. The narration alternates between the past and the present; the tale of the past is dependent on the present and is sometimes interrupted by it. Grace lives in two worlds and endows both of them with some aspects of each other. She controls the past through her tale and can pause it and return to it at her convenience. The past thus becomes removed from the standard passage of time. Grace revisits the past at her own pace, sometimes admitting that she jumps too far ahead in her tale. She is conscious of her double role: on the one hand, she is a character in the story, oblivious of being scrutinised by her future self, but on the other hand, she is the commentator and the judge. Sometimes the latter slips into the former, threatening to colour the events with her hindsight. Grace admits to the temptation to edit some of her reactions but she concludes: "[b]ut to do

16 C. Monk, Heritage Film Audiences: Period Films and Contemporary Audiences in the UK, Edinburgh 2011, p. 1.

17 Ibid., p. 2. 
so would be crediting my young self with empathy I did not possess" (THR 56). Moosavinia and Almasi link literary recollections with the concept of "the multiplicity of consciousness", where past experiences coexist with the character's present existence. ${ }^{18}$ This is true for Grace as her mind seems to be inhabited by two different versions of herself at the same time.

Grace's secret is that Robbie did not kill himself - it was Hannah who shot him to protect her sister. Consequently, there exist two versions of the past - the one that has been passed on from generation to generation, and the other that Grace has been hiding. The past has been revived and she is "beginning to feel at home in the past and a visitor to this strange and blanched experience we agree to call the present" (THR 104). Once she has finished her tale, she can die, her mission complete.

\section{Conclusion}

To conclude, repetition in The House at Riverton manifests itself in drawing on the appeal of nostalgia and the reconstruction of the past by means of a historical film and tape recordings. The novel emphasises the fact that all the future renditions of an event or a story cannot be their identical reproductions. Although they have many similarities, $21^{\text {st }}$-century novels, films, and TV series set in the early $20^{\text {th }}$ century offer new perspectives on the past, often serving as a commentary on important social issues. Randall Stevenson claims: "Since this past experience often seems more alluring or coherent than present consciousness - especially if Orwell is right about remembering the pleasant bits - it might be that narrative is to an extent inherently nostalgic". ${ }^{19}$ However, it should be noted that the nostalgia in The House at Riverton is used to attract readers but the novel dispels the myth of the past instead of glorifying it. The past is reconstructed with many of its nuances but it is only an imitation, a replica. Grace concludes that "[...] time erases real lives, leaving only vague imprints" (THR 30-31).

18 S.R. Moosavinia, Y. Almasi, Psychological Time in Mrs. Dalloway, "The Atlantic Literary Review" 2013, vol. 14, no. 4, p. 7-8.

19 R. Stevenson, op. cit., p. 137. 


\section{Bibliography}

Monk C., Heritage Film Audiences: Period Films and Contemporary Audiences in the UK, Edinburgh 2011.

Moosavinia S.R., Almasi Y., Psychological Time in Mrs. Dalloway, "The Atlantic... Literary Review" 2013, vol. 14, no. 4, p. 1-12.

Morton K., The House at Riverton, London 2007.

Powell L., The Lake House Author Kate Morton: I Wrote The House at Riverton During my Baby's Naptimes', "The Telegraph" 2016, 14 May,

https://www.telegraph.co.uk/books/authors/the-lake-house-author-kate-morton-i-wrote-the-house-at-riverton/ (access: 28.03.2018).

Rosenstone R.A., The Reel Joan of Arc: Reflections on the Theory and Practice of the Historical Film, "The Public Historian" 2003, vol. 25, no. 3, p. 61-77.

Stevenson R., Remembering the Pleasant Bits: Nostalgia and the Legacies of Modernism, "NOVEL: A Forum on Fiction" 2010, vol. 43, no. 1, p. 132-139.

Su J.J., Ethics and Nostalgia in the Contemporary Novel, Cambridge 2005.

Tamarkin E., Anglophilia: Deference, Devotion, and Antebellum America, ChicagoLondon 2007.

Taylor D.J., Bright Young People: The Rise and Fall of a Generation: 1918-1940, London 2007.

Tuchman B.W., The Guns of August, London 1962.

Waugh E., Brideshead Revisited, London 2011.

Welsh J.M., Hollywood "Faction" and the New Biofantasy, "Studies in Popular Culture" 1993, vol. 15, no. 2, p. 57-66. 